suggest that pattern may contribute to the epileptogenic effect of TV. The most obvious linear pattern stimulation from a black and white television set is provided by the raster as it scans across the screen. Half frames of alternate lines are emitted at $50 \mathrm{~Hz}$; the lines interlace and thus give an effective displacement of the retinal image similar to that produced by horizontal lines vibrating at $25 \mathrm{~Hz}$. On black and white TVs in areas of low signal strength there is also a small up and down motion of the raster producing so called "line jitter." This last phenomenon may have some relevance to our study as Runwell Hospital lies in a valley where signal strength is low. Aberrations such as line jitter are accepted as normal by domestic viewers but are not seen on studio-quality equipment and may account for the discrepancy between the high incidence of TV sensitivity reported by us $^{8}{ }^{9}$ and by others, ${ }^{7}$ and the failure of Gastaut $e t a l^{6}$ to show television sensitivity in the studios of the French national broadcasting organisation.

This work was supported by grants from the British Epilepsy Association, The Drapers' Company, and the North-east Thames
Regional Health Authority. We are grateful to those colleagues who have allowed us to investigate patients under their care and particularly to Drs $\mathrm{H}$ Liebeschuetz and A Banister. We also wish to acknowledge the technical advice of Mr L G Pugh and the BBC.

\section{References}

1 Jeavons, P M, and Harding, G F A, Photosensitive Epilepsy, London, Heinemann, 1975.

2 Charlton, M H, and Hoefer, P F A, Archives of Neurology, 1964, 2, 239.

${ }^{3}$ Andermann, F, Epilepsia, 1971, 12, 269.

4 Wilkins, A J, Andermann, F, and Ives, J, Brain, 1975, 98, 365

${ }^{5}$ Bickford, R G, and Klass, D W, in Basic Mechanisms of the Epilepsies, ed H H Jasper, A S Ward, and A Pope, p 543. London, Churchill, 1969.

6 Gastaut, H, Regis, H, and Bostem, F, Epilepsia, 1962, 3, 438.

${ }^{7}$ Connell, B, et al, fournal of Electrophysiological Technology, 1975, 1, 281.

${ }^{8}$ Binnie, C D, Darby, C E, and Hindley, A T, British Medical fournal, 1973, 4, 378.

${ }^{9}$ Darby, C E, and Hindley, A T, Proceedings and Fournal of the ElectroPhysiological Technologists' Association, 1974, 21, 4.

(Accepted 6 May 1977)

\title{
Cardiovascular and sympathetic response to exercise after long-term beta-adrenergic blockade
}

\author{
A E G RAINE, T G PICKERING
}

British Medical fournal, 1977, 2, 90-92

\begin{abstract}
Summary
The response to dynamic exercise was investigated in 21 patients receiving long-term treatment with betaadrenoceptor antagonists and 22 controls. An electrocardiogram (ECG) and blood pressure were recorded before and after treadmill exercise, and plasma dopamine- $\beta$-hydroxylase (DBH) activity was measured as an index of changes in sympathetic activity. Heart rate and blood pressure were lower at rest and throughout exercise in treated patients, although the pressor effect of exercise was not reduced. The ECG $P-R$ interval was lengthened, and in addition the $Q-T$ interval was prolonged. After exercise, plasma DBH activity was significantly increased in controls but not in treated patients. We conclude that long-term administration of betaadrenergic blockers increases myocardial repolarisation time and reduces sympathetic nervous activity. These actions may contribute to the antiarrhythmic and hypotensive effects of long-term beta-blockade.
\end{abstract}

\section{Introduction}

Beta-adrenoceptor antagonists are widely used in hypertensive and ischaemic heart disease, yet despite their proved clinical

Cardiac Department, The Radcliffe Infirmary, Oxford OX2 6HE

A E G RAINE, BMEDSC, $M B$, research registrar

T G PICKERING, DPHIL, MRCP, lecturer (present address: The New York Hospital, Cornell Medical Centre, 525 East 68th Street, New York, NY 10021) value their therapeutic mode of action is not fully understood. The mechanism by which they lower blood pressure is the subject of continuing controversy, ${ }^{1}$ and, more important, the basis of their protective action after myocardial infarction ${ }^{2}$ remains to be established. Most investigations of the actions of beta-adrenergic antagonists in man have centred on their shortterm effects: they cause an immediate reduction in cardiac output but arterial blood pressure is unchanged. ${ }^{3}$ In contrast, long-term administration of beta-blockers produces a welldocumented fall in blood pressure, which may be maximal only after several weeks ${ }^{4}$ and is associated with a recuction in peripheral resistance. ${ }^{5}$ Acute beta-adrenergic blockade produces reflex sympathetic hyperactivity, ${ }^{6}$ but studies on animals have suggested that long-term beta-blockade may reduce sympathetic nervous system activity. ' Long-term treatment also prolongs the repolarisation time of the cardiac action potential in animals, ${ }^{*}$ an effect that is known to be antiarrhythmic.

We therefore decided to evaluate in patients the effects of long-term beta-adrenergic blockade on sympathetic function and cardiac repolarisation time. Changes in plasma activity of the noradrenaline-synthesising enzyme dopamine- $\beta$-hydroxylase $(\mathrm{DBH})$ after exercise were used as an index of sympathetic activity. The effects of prolonged beta-blockade on the electrocardiogram (ECG) and on blood pressure at rest and after exercise were also investigated.

\section{Patients and methods}

Two matched groups of patients were studied-21 aged 44-60 years who had been receiving beta-adrenergic blocking drugs for at least three weeks, and 22 aged 31-78 years who were not being treated and served as controls. The two groups were closely similar clinically (table I) and were matched for exercise tolerance, the mean maximal exercise time being the same in both groups (see Results). All the patients had been referred to the cardiac department for diagnostic maximal treadmill exercise testing. Table II gives the beta-blocker regimens in the treated group. No differences were observed between 
TABLE I-Clinical details of patients studied

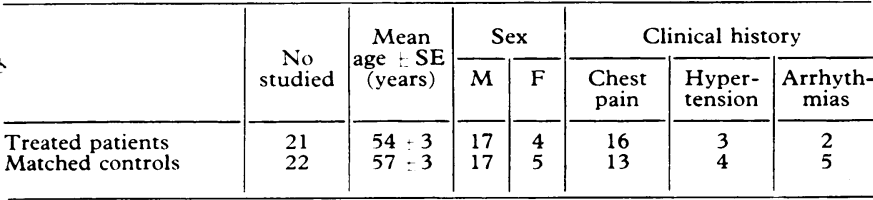

TABLE II-Beta-blocker regimens in treated patients

\begin{tabular}{l|c|c|c}
\hline \multicolumn{1}{c|}{ Drug } & $\begin{array}{c}\text { No of } \\
\text { patients }\end{array}$ & $\begin{array}{c}\text { Mean daily dose } \\
\text { in mg (range) }\end{array}$ & Additional drugs \\
\cline { 2 - 2 } $\begin{array}{l}\text { Propranolol } \\
\text { Oxprenolol }\end{array}$ & 6 & $176(40-480)$ & Diuretic (1), clonidine (1) \\
Atenolol & 3 & $167(120-640)$ & Perhexiline (1) \\
Metoprolol & 1 & 150 & Diuretic (2) +hydrallazine (1) \\
Acebutolol & 1 & 200 & \\
\hline
\end{tabular}

the beta-blockers for any of the variables studied, and so results for the treated patients are pooled.

All patients were investigated by means of a standard protocol. After 30 minutes' rest a $10-\mathrm{ml}$ blood sample was collected by vene(puncture and supine and standing blood pressures were measured with a sphygmomanometer and arm cuff. The ECG was recorded at 50 $\mathrm{mm} / \mathrm{s}$ at rest, precordial leads (modified lead II) being used. Patients were then exercised on a treadmill according to a modified Bruce protocol $^{9}$ till the onset of chest pain or severe fatigue. Heart rate was recorded after each three minutes of exercise. Immediately after stopping exercise standing and supine blood pressure measurements were repeated and a further ECG was recurded. One minute after completing exercise a second blood sample was taken. Both blood samples were centrifuged at $4{ }^{\circ} \mathrm{C}$, the plasma being stored at $-20^{\circ} \mathrm{C}$ until assay. R-R, P-R, and Q-T intervals and QRS widths in the ECGs were measured, and $Q-T_{C}$. was derived by using the Bazzett formula.

Plasma DBH activity was measured in $25-u l$ aliquots with the double enzyme radiometric method of Weinshilboum and Axelrod, ${ }^{10}$ phenylethylamine being used as substrate. Internal standards of phenylethanolamine and stock plasma were included in all assays. One unit of DBH activity represented the formation of $1 \mathrm{nmol}$ phenylethanolamine per $\mathrm{ml}$ of plasma per hour. Plasma propranolol concentration was measured in all patients receiving this drug with a modification of the fluorometric method of Shand et al. ${ }^{11}$

The significance of differences between groups and of paired differences within groups were evaluated by means of Student's $t$ test. Results are expressed as mean \pm SE of mean.

TABLE III-Mean supine and standing blood pressures $\pm S E(\mathrm{~mm} \mathrm{Hg})$ in treated patients and matched controls at rest and after treadmill exercise

\begin{tabular}{|c|c|c|c|c|c|c|}
\hline & \multicolumn{3}{|c|}{ Supine } & \multicolumn{3}{|c|}{ Standing } \\
\hline & Systolic & Diastolic & Mean & Systolic & Diastolic & Mean \\
\hline \multicolumn{7}{|c|}{ Treated patients } \\
\hline $\begin{array}{l}\text { At rest } \\
\text { After exercise }\end{array}$ & $\begin{array}{l:l}130 & 6 \\
155 & 6\end{array}$ & $\begin{array}{l}76: 3 \\
84: 3\end{array}$ & $\begin{array}{r}93: 3 \\
109: 4\end{array}$ & $\begin{array}{l}126 \div 5 \\
164: 6\end{array}$ & $\begin{array}{l}82: 3 \\
90: 3\end{array}$ & $\begin{array}{r}96 \div 4 \\
115 \div 4\end{array}$ \\
\hline \multicolumn{7}{|c|}{ Matched controls } \\
\hline $\begin{array}{l}\text { At rest } \\
\text { After exercise }\end{array}$ & $\begin{array}{l:l}141 & 7 \\
174 & 8\end{array}$ & $\begin{array}{l}82: 4 \\
88: 4\end{array}$ & $\begin{array}{l}102: 5 \\
117: 5\end{array}$ & 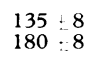 & $\begin{array}{l}86: 4 \\
92: 4\end{array}$ & $\begin{array}{l}102 \div 5 \\
122 \div 5\end{array}$ \\
\hline
\end{tabular}

\section{Results}

Most patients completed three stages of exercise, and some four. Mean exercise time for the 21 treated patients was $8.1 \pm 0.6 \mathrm{~min}$, and for the 22 matched controls $8 \cdot 1 \pm 0 \cdot 3 \mathrm{~min}$. In both groups the heart rate increased linearly with successive stages of exercise (fig 1). At rest and throughout exercise, however, it was lower $(P<0.001)$ in the treated patients.

Systolic, diastolic, and mean blood pressures were lower at rest in the treated group (table III). No patients showed postural hypotension, and overall there was no noticeable change in blood pressure on standing in either group. After exercise the systolic, diastolic, and mean pressures were consistently higher in both groups. The rise in mean arterial pressure after exercise in the treated group $(15 \pm 3 \mathrm{~mm})$ was the same as in the controls $(15 \pm 4 \mathrm{~mm})$.

Table IV shows the effects of long-term beta-blockade on the ECG at rest and after exercise. The R-R interval was longer with treatment, reflecting the lower heart rate. The P-R interval was longer in treated patients at rest and after exercise. QRS width was the same in both groups. There was significant lengthening of the Q-T interval at rest and after exercise in the treated patients, and when corrected for heart rate $\mathrm{Q}-\mathrm{T}_{\mathrm{C}}$ in both groups was similar. After exercise $\mathrm{Q}-\mathrm{T}_{\mathrm{c}}$ shortened significantly $(P<0.01)$ in the controls but was slightly longer in the treated group

Plasma DBH activity at rest varied widely in the two groups (fig 2). Mean DBH activity was lower in the treated group $(58.5 \pm 9.4 \mathrm{U})$ than in the controls $(72 \cdot 9 \pm 7 \cdot 8 \mathrm{U})$ but not significantly so. After maximal treadmill exercise the mean plasma DBH activity in the controls increased by $15.5 \pm 4.1 \mathrm{U}(\mathrm{P}<0.002)$. In contrast, in patients on long-term beta-blockade the increase in DBH activity after equal exercise was small and variable (mean $4 \cdot 3 \pm 2 \cdot 2 \mathrm{U} ; \mathrm{NS}$ ). This reduction was not related to dose or to specific beta-adrenergic antagonists. No correlation was observed between plasma DBH activity and blood pressure or heart rate, or between DBH activity and age.

Plasma propranolol concentrations were measured in nine patients being treated with this drug: the mean concentration was $199 \mathrm{nmol} / \mathrm{l}$ $(66 \mathrm{ng} / \mathrm{ml})$, and the range $102-373 \mathrm{nmol} / 1(34-124 \mathrm{ng} / \mathrm{ml})$.

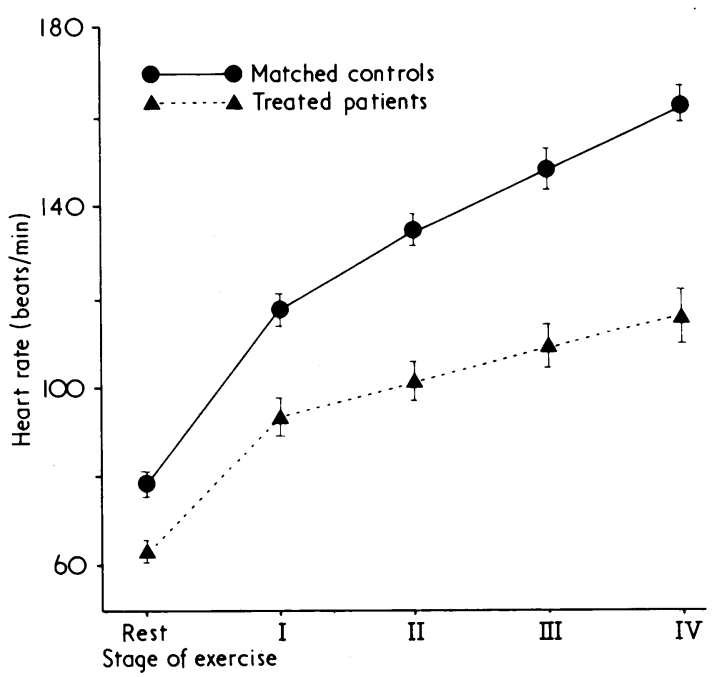

FIG $1-$ Mean heart rates at rest and during treadmill exercise in treated patients and matched controls. Points are $\pm S E$ of means.

TABLE IV-Mean ECG durations $\pm S E$ (seconds) in treated patients and matched controls at rest and immediately after exercise

\begin{tabular}{|c|c|c|c|c|c|c|c|c|c|c|}
\hline & \multicolumn{2}{|c|}{$\mathrm{R}-\mathrm{R}$} & \multicolumn{2}{|c|}{ P-R } & \multicolumn{2}{|c|}{ QRS } & \multicolumn{2}{|c|}{ Q-T } & \multicolumn{2}{|c|}{ Q-Tc } \\
\hline & $\begin{array}{c}\text { At } \\
\text { rest }\end{array}$ & $\begin{array}{l}\text { After } \\
\text { exercise }\end{array}$ & $\begin{array}{l}\text { At } \\
\text { rest }\end{array}$ & $\begin{array}{l}\text { After } \\
\text { exercise }\end{array}$ & $\begin{array}{l}\text { At } \\
\text { rest }\end{array}$ & $\begin{array}{c}\text { After } \\
\text { exercise }\end{array}$ & $\begin{array}{c}\text { At } \\
\text { rest }\end{array}$ & $\begin{array}{c}\text { After } \\
\text { exercise }\end{array}$ & $\begin{array}{c}\text { At } \\
\text { rest }\end{array}$ & $\begin{array}{l}\text { After } \\
\text { exercise }\end{array}$ \\
\hline $\begin{array}{l}\text { Treated patients } \\
\text { Matched controls }\end{array}$ & $\begin{array}{l:l}0.99 & 0.04 \\
0.81 & 0.03\end{array}$ & $\begin{array}{l}0.64: 0.04 \\
0.45: 0.02\end{array}$ & $\begin{array}{l}0 \cdot 16: 0.01 \\
0.14 \\
0.01\end{array}$ & $\begin{array}{l}0.15 \pm 0.01 \\
0.13 \div 0.01\end{array}$ & $\begin{array}{l}0.08: 0.01 \\
0.08: 0.01\end{array}$ & $\begin{array}{ll}0.08 & -0.01 \\
0.08 & 0.01\end{array}$ & $\begin{array}{l}0.40 \div 0.01 \\
0.38 \div 0.01\end{array}$ & $\begin{array}{l}0.33 \pm 0.01 \\
0.27 \pm 0.01\end{array}$ & $\begin{array}{l}0.41+0.01 \\
0.42+0.01\end{array}$ & $\begin{array}{l}0.42 \pm 0.01 \\
0.40 \pm 0.01\end{array}$ \\
\hline$P$ & $<0.005$ & $<0.001$ & $<0.02$ & $<0.02$ & NS & NS & $<0.025$ & $<0.001$ & NS & NS \\
\hline
\end{tabular}




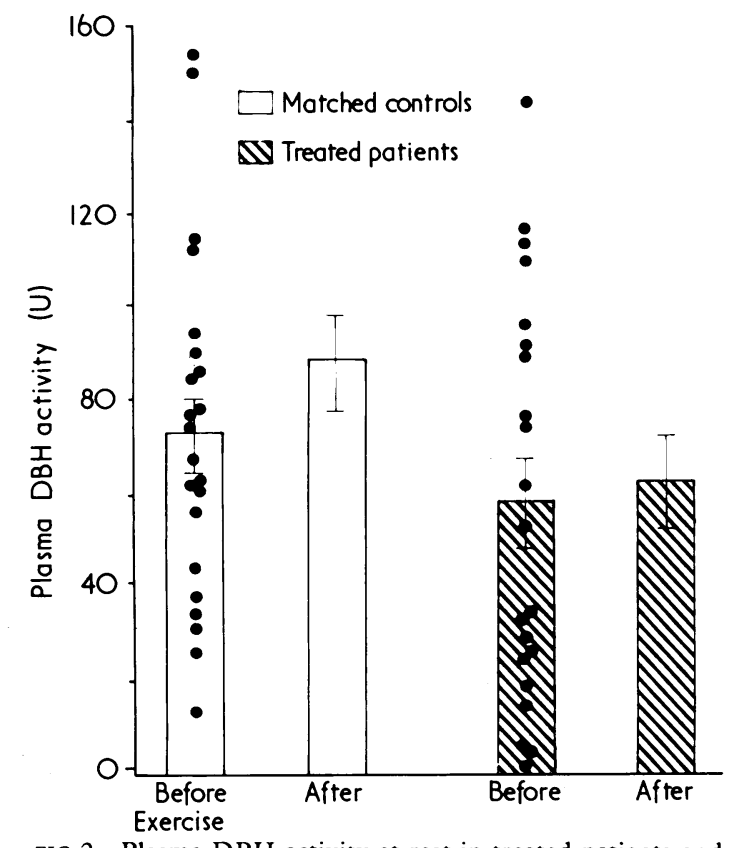

FIG 2-Plasma DBH activity at rest in treated patients and matched controls, and effect of treadmill exercise on mean ( \pm SE of mean) DBH activity.

\section{Discussion}

Blood pressures in the patients receiving beta-blockers were uniformly lower than in the controls owing to the hypotensive effect of long-term beta-adrenergic blockade. Heart rates at rest and during exercise were also lower in the treated group, suggesting adequate continuous cardiac beta-blockade. Plasma propranolol concentrations in the patients receiving this drug were within the therapeutic range. ${ }^{12}$

Somewhat surprisingly, the rise in blood pressure with exercise was the same in both groups. We know that the pressor effect of dynamic exercise is reduced by acute beta-adrenergic blockade-see, for example, Shinebourne et $a l^{13}$-but whether this is so during long-term beta-blockade is less clearly established. While some studies suggest that the pressor effect of exercise is reduced during long-term treatment, ${ }^{14}$ others do not. ${ }^{15}$

Long-term effects of beta-blockade on the ECG were observed on both the P-R and Q-T intervals. Acute administration of propranolol prolongs the $\mathrm{P}-\mathrm{R}$ interval, ${ }^{16}$ and our results indicate that this effect is maintained during long-term treatment. Prolongation of the P-R interval may reflect a slowing of atrioventricular conduction by beta-adrenergic blockers, and this has been directly demonstrated by His-bundle electrocardiography. ${ }^{17}$

In contrast, acute administration of a beta-blocking drug has no effect on QRS width or Q-T interval. ${ }^{18}$ In fact, when corrected for lower heart rate $\mathrm{Q}-\mathrm{T}_{\mathrm{C}}$ is shortened. In our series, however, although the QRS width remained unchanged after long-term beta-blockade, the Q-T interval was significantly shorter in the controls. After rate correction $Q_{-} \mathrm{T}_{C}$ in the two groups was similar. With a maintained reduction in heart rate the ventricular repolarisation time may gradually lengthen, so that in the long term it occupies the same proportionate length of the cardiac cycle as it did before treatment. Microelectrode studies of rabbit cardiac muscle ${ }^{x}$ have shown that prolonged beta-blockade significantly lengthens atrial and ventricular action potentials in animals in contrast to the absence of any effect of acute beta-blockade on cardiac action potential duration. ${ }^{19} \mathrm{~A}$ similar long-term increase in cardiac repolarisation time may occur in patients on long-term beta-blocker treatment.
If so, this may partly explain the protective antiarrhythmic effect of long-term treatment after myocardial infarction."

The final aim of our study was to investigate the long-term effect of beta-adrenergic blockers on the sympathetic nervous system. Although several stimuli such as exercise, tilt, and cold pressor tests are commonly used clinically to provoke increases in sympathetic activity, these increases have proved difficult to quantify. The knowledge that $\mathrm{DBH}$ is released from the presynaptic vesicles of sympathetic nerves together with noradrenaline ${ }^{20}$ suggests that measurements of plasma $\mathrm{DBH}$ activity may be clinically useful as an "index" of sympathetic activity. Mean DBH activity in our patients was lower in those receiving beta-blocker treatment but the difference was not significant. There were, however, pronounced differences in $\mathrm{DBH}$ response after treadmill exercise between the two groups. Plasma DBH activity is significantly increased after maximal exercise, ${ }^{21}$ and we found this in our controls. In contrast, there was no such change in the treated patients after exercise for the same length of time. Studies on animals have shown that prolonged beta-blockade produces a significant fall in DBH activity in sympathetic ganglia. ' Our results suggest that in man also long-term beta-adrenergic blockade may reduce sympathetic activity. Most of our patients were normotensive, but if beta-blockers have a similar long-term effect in hypertensive patients it may partly explain how these drugs reduce peripheral resistance and hence arterial pressure.

In conclusion, these effects of long-term beta-blockade on blood pressure, the ECG, and sympathetic activity may all be part of an overall response to treatment. Although the effects of cardiac sympathetic activity on the Q-T interval are complex, ${ }^{2 ! 2}$ experimental sympathectomy causes $\mathrm{Q}-\mathrm{T}$ prolongation. ${ }^{23}$ Our findings suggest that there is a long-term adaptive response to long-term beta-adrenergic blockade that includes reduced sympathetic activity and increased myocardial repolarisation time. These effects are quite distinct from the acute effects of beta-blockers and may be of major therapeutic importance.

We thank Dr E M Vaughan Williams and Professor P Sleight for their advice and encouragement. AEGR is supported by a British Heart Foundation junior fellowship.

\section{References}

${ }^{1}$ Fitzgerald, J D, Postgraduate Medical fournal, 1976, 52, suppl No 4, p 184. 2 Green, K G, et al, British Medical fournal, 1975, 3, 735.

${ }^{3}$ Ulrych, M, et al, Circulation, 1968, 37, 411.

4 Prichard, B N C, and Gillam, P M S, British Medical fournal, 1969, 1, 7.

5 Tarazi, R C, and Dustan, H P, American fournal of Cardiology, 1972, 29, 633.

${ }^{6}$ Irving, M H, et al, Nature, 1974, 248, 531.

7 Raine, A E G, and Chubb, I W, Nature. 1977, 267, 265.

'Raine, A E G, and Vaughan Williams, E M, British Heart fournal, 1976, 38, 873 .

${ }^{9}$ Doan, A E, et al, American Heart fournal, 1965, 69, 11.

11) Weinshilboum, R, and Axelrod, J, Circulation Research, 1971, 28, 307.

1 Shand, D G, Nuckolls, E M, and Oates, J A, Clinical Pharmacology and Therapeutics, $1970,11,112$.

12 Coltart, D J, and Shand, D G, British Medical fournal, 1970, 3, 731.

13 Shinebourne, E, Fleming, J, and Hamer, J, Lancet, 1967, 2, 1217.

14 Davidson, C, et al, British Medical fournal, 1976, 2, 7.

15 Lund-Johansen, P, Acta Medica Scandinavica, 1974, 195, 117.

${ }_{16}$ Stern, S, and Eisenberg, S, American Heart fournal, 1969, 77, 192.

1 : Smithen, C S, Balcon, R, and Sowton, E, British Heart fournal, 1971, 33, 955.

18 Seides, S F, et al, American Heart fournal, 1974, 88, 733.

19 Papp, J G, and Vaughan Williams, E M, British fournal of Pharmacology, $1969,37,391$.

20 Geffen, L B, and Livett, B G, Physiological Reviews, 1971, 51, 98.

${ }^{21}$ Planz, G, and Palm, D, European Fournal of Clinical Pharmacology, 1973, 5, 255.

$\because 2$ Schwartz, P J, Periti, M, and Malliani, A, American Heart fournal, 1975, $89,378$.

${ }^{23}$ Yanowitz, F, Preston, J B, and Abildskov, J A, Circulation Research, 1966, $18,416$.

(Accepted 3 May 1977) 